\title{
Modular Force Structure: Risk for NATO Common Defence?
}

\section{Modulární struktura vojsk: riziko pro společnou obranu NATO?}

\section{Karel Zetocha}

Abstract: The concept of modular forces seems to be an ideal solution for a topical dilemma: how to build a single set of units for a wide range of military operations. However, the concept of unit modularity has its limitations. The article explains how the modular force structure supports flexibility and consequently brings increased demand on the number of support units. For this reason, the modular force organisation cannot be built without massive investment in support capabilities. The concept of modularity includes the risk that shortage of support units will significantly limit the readiness of forces for a large conventional war. The author presents four recommendations for the application of the concept of modularity at a national level to facilitate the formation of allied forces.

Abstrakt: Koncept modulárních sil se zdá být ideálním řešením pro aktuální dilema: jak vytvořit jeden soubor sil pro širokou škálu vojenských operací. Avšak koncept modulárních jednotek má i svá omezení. Článek vysvětluje, jak modulární struktura sil podporuje flexibilitu a proč následně přináší zvýšený požadavek na počet podpůrných jednotek. Z tohoto důvodu nelze modulární armádu vybudovat bez masivních investic do schopností podpory. Koncepce modularity zahrnuje riziko, že nedostatek podpůrných jednotek výrazně omezí připravenost sil pro rozsáhlou konvenční válku. Autor předkládá čtyři doporučení pro aplikaci konceptu modularity na národní úrovni pro usnadnění formování aliančních sil.

Key words: $\quad$ Army of the Czech Republic; Modularity; NATO; Structure Adaptation; Warfighting Functions.

Klíčová slova: Armáda České republiky; modularita; NATO; struktura jednotek; bojové funkce. 


\section{INTRODUCTION}

In the 2014, NATO and its member states were forced to refocus on the defence of their own soil. A conflict with large conventional forces, again, became a relevant topic for force planning. Compared to expeditionary COIN and stabilisation operations, the extensive conventional conflict represents a completely different operational environment. Armed forces of NATO states face the dilemma how to be prepared for a large variety of different operations with a short notice time. The modular force structure principle has become one of the tools to solve the dilemma and enable rapid and flexible reaction. ${ }^{1}$

The aim of the text is to examine the potential of the modular force concept and its limits. The core argument is that the modular force structure supports flexibility but it simultaneously limits readiness if applied in an inappropriate way. Possible solution could be offered by the warfighting function concept, which may be used as an analytical tool to evaluate the combat unit structure from the point of view of readiness. A coordinated approach to modular force structure is a necessary condition for conducting large scale operations at the NATO level.

To verify this argument, it is firstly necessary to clarify basic term definitions. Secondly, the origins and modifications of the modular force concept will be examined. Further elementary relations between the operational environment and force structure will be shown. The next step of the analysis will be to demonstrate that, unlike unit structure, warfighting functions are constant regardless of the specific operation environment. The final part will be to present recommendations based on the findings of the analysis.

\section{TERMINOLOGY}

First, it is necessary to explain the meaning of basic terms connected with modularity. According to NATO's definition, interoperability is a general term: "The ability to act together coherently, effectively and efficiently to achieve Allied tactical, operational and strategic objectives." 2 More specific and useful is the term force interoperability: "The ability of the forces of two or more nations to train, exercise and operate effectively together in the execution of assigned missions and tasks". 3 The desired level of force interoperability is achieved through maintaining compatibility, ${ }^{4}$ interchangeability $^{5}$ or

1 For example, Ministry of Defence of The Czech Republic: The Long Term Perspective for Defence 2030, Prague 2015, p. 10.

2 Allied Joint Doctrine For Land Operations, ATP-3.2., NATO Standardization Agency, 2016, p. 84.

3 APP-6, Slovník NATO s termíny a definicemi, Úřad pro obrannou standardizaci, Praha 2015, p. 151.

4 Compatibility: "The suitability of products, processes or services for use together under specific conditions to fulfil relevant requirements without causing unacceptable interactions." Ibid. p. 91.

5 Interchangeability: "The ability of one product, process or service to be used in place of another to fulfil the same requirements." Ibid. p. 185. 
commonality. ${ }^{6}$ All of the above-mentioned drivers of interoperability are reached through the NATO's process of standardisation. ${ }^{7}$ The Alliance standardises concepts, doctrines, procedures and designs, nevertheless, reaching an agreement on the organisational structure of forces is far more difficult. The modularity refers to standardised units that can be replaced during ongoing operations. NATO's definition of interchangeability refers to product, process or service, however, unit structure (modularity) is not a domain of NATO standardisation.

\section{ORIGINS OF THE CONCEPT OF MODULAR FORCE}

The origins of modular concept can be found in USA in the 1990s. Generally, the principle of force modularity was a reaction to operational demands rising mainly from expeditionary operations. In the beginning, it was also a reaction to the budget cuts after the end of the Cold War. The concept of modular forces stems from the transformation of the structure of the US Army. Since 2003, the traditional structure of division-based forces has been transformed into a Brigade-based structure and Brigade combat teams. The creation of a modular structure of forces was a response to the intensive deployment of the military to expeditionary operations in Iraq and Afghanistan. These were stabilisation operations, a significant part of which was a counter-insurgency struggle. The nature of the operating environment required greater operational independence for commanders at a lower level than the traditional division. The operational need led to the creation of separate brigades that could be assigned to the operation commander according to a specific operation. ${ }^{8}$

Combat and Support Brigades are allocated to the Joint Force Commander in the power generation process. The structure of forces based on unified brigades has been referred to as modular forces. The primary feature of modularity in the US Army's concept is to increase combat support and service capabilities and allocate them to a brigade level. The reorganisation allowed the deployment of organic brigades into expedition operations. Another feature of the reorganisation of the US Army was the unification of organic brigades that allowed them to rotate. " "Modularity would create a more efficient way of organizing a force with more standardized brigades, enabling direct interchangeability when it is necessary to replace a unit."10

6 Commonality: "The state achieved when the same doctrine, procedures or equipment are used." Ibid. p. 89.

7 Standardisation: "The development and implementation of concepts, doctrines, procedures and designs in order to achieve and maintain the compatibility, interchangeability or commonality which are necessary to attain the required level of interoperability, or to optimise the use of resources, in the fields of operations, materiel and administration." Ibid. p. 306.

8 Stuart E. Johnson, John E. Peters, Karin E. Kitchens, Aaron Martin, A Review of the Army's Modular Force Structure, RAND Corporation, 2011, pp. 7-12.

9 FMI 3-0.1, The Modular Force, Headquarters, Department of the Army, 2008.

10 Stuart E. Johnson, John E. Peters, Karin E. Kitchens, Aaron Martin, A Review of the Army's Modular Force Structure, RAND Corporation, 2011, p. 11. 
To sum it up, the most important parts of modularity were:

1. unification of brigade-level combat unites;

2. brigade combat teams have some level of CS a CSS capabilities - can operate without support from the division level;

3. standardised support brigades were created;

4. joint operational commander gets tailored task force - mix of BCT, support brigades and other components. ${ }^{11}$

\section{DEVIATIONS IN MODULARITY}

The concept of modular forces has always been meant to be a suitable solution for the rapidly developing security environment and operational needs of actual operations. However, the original concept must be supplemented by the capabilities required to conduct high-intensity operations. A properly grasped organisational modularity supports the flexibility of the units and is a precondition for achieving interoperability. Nevertheless, the approach of the most of the European NATO member states to the concept of modular forces has been far different from the US Army's one. Smaller states are not able to deploy brigades into operations regularly and thus create task forces and modules at lower organisational levels.

An extreme example of the understanding of modularity as the possibility of decomposition and mixing of tactical units up to individual crews was represented by the Doctrine of the Army of the Czech Republic from 2010. ${ }^{12}$ Later, the understanding of modularity developed. However, the Czech Army's doctrine further describes modularity as the composition of task forces from the lowest tactical level according to current needs. "Modular system consists of gradual integration of modules into a functional system according to specific requirements. For the purposes of operational deployment, basic modules are selected that are structured into organisational components in order to create the desired task force. The specific capability requirements for a particular operation determine the size, structure, and composition of the task force that will vary with each operation."13

Also, budgetary cuts on the European side of the Atlantic Ocean were far more severe than in the USA. The hypothesis of a long reaction time for a high intensity conflict

11 Fruitful inside in US approach to modular force transformation provided Kugler: Richard L. Kugler. Case Study in Army Transformation: Creating Modular Forces, Case Studies in National Security Transformation, Number 14, National Defense University, 2008.

12 Modularity: "... the basis of the structure of the army. Original modular tactical elements form national and multinational task forces. Their qualitative and quantitative parameters must match the nature of the tasks to be performed. Units of all kinds of troops and services of different levels of command are detached for the need to establish joint multinational task forces. Capabilities will be tailored to the specific needs of the operation. The basic modular element is the team/crew/operator level." Doctrine of the Army of the Czech Republic, Ministry of Defence of the Czech Republic, 2010. p. 108.

13 Doctrine of the Army of the Czech Republic, Ministry of Defence of the Czech Republic, 2013. p. 44. 
was accepted as undeniable and used as an argument to justify decreasing investments in national defence. The "relaxed" security assumption was also adopted by smaller NATO members and the Czech Republic was no exception: "The outbreak of a large armed conflict affecting the territory of the Czech Republic or the territory of other NATO member states is highly unlikely in the foreseeable time horizon; potential threat would be detected well in advance allowing to take effective action." 14 The concept of modular forces was often misused as a cover for military weakness. The modularity has become a synonym for sharing a single set of CS and CSS capabilities between more combat units (ground and even air force). It is important to stress that such a situation cannot be called the modular force. It is to be described as the lack of capabilities. Modularity cannot represent a way to save on investments in defence. On the contrary, the requirement for unit independence at a lower tactical level requires a larger number of CS and CSS units.

\section{OPERATIONAL ENVIRONMENT AND FORCE STRUCTURE}

Two basic kinds of combat operational environments can be identified: high intensity combat with a capable adversary (state) or lower intensity combat within the framework of stability and COIN operations. It is clear that the operational environment in a conventional high intensity conflict is far different from the operating environment of a stabilisation operation. A significant difference is in the operational tempo and the time to prepare the units. There is a stable operating environment in the stabilisation operation after the initial crisis response. Combat units regularly rotate and have standard time to prepare before deployment. Long-term deployment of units on a rotating basis allows the formation of task forces at the lowest tactical level. Sufficient preparation time allows creating new organisational structures and unit training. ${ }^{15}$

In the conflict with a conventional enemy, conditions are different. A strong enemy takes full advantage of the time it is given to gain a more favourable position. The aggressor must be prevented from achieving the objectives of the operation. Later reactions allow aggressors to meet the objectives of the operation and to stabilise their gains. Therefore, such a situation requires larger force formations ready to move at short notice and a robust combat structure to react.

The modular force concept was developed to meet the operational needs of stability and COIN operations. Therefore, an inherent part of the modular force concept was the assumption that there will be enough time to compose larger forces, if necessary: "One potential source of operational risk lies with more capable adversaries, though

14 Military Strategy of the Czech Republic, Ministry of Defence of The Czech Republic, Prague 2004, p. 6.

15 For more details on the operational environment topic, see, for example: Pikner, Ivo, Spišák, Ján, Galatík, Vlastimil, Zůna, Pavel. Military Operating Concepts Development. SHOPMYBOOK, Peleman Industries NV, Belgium, 2013, pp. 28-29, ISBN 978-16-1627-370-5. 
none looms on the horizon....If more capable foes begin to emerge, the Army would have time to adapt accordingly."16

The above-mentioned "would have time" assumption turned out to be completely false no later than in 2014. It clearly showed an example of rapid development in the conflict with a capable adversary. Borders of NATO and its partners can be under military threat with a very limited time for the allied response. Therefore, the NATO forces must be ready to conduct limited stabilisation operations abroad as well as plausibly deter well-orchestrated aggression of international powers.

The current operating environment requires forces that are capable of rapid response to a wide range of operations including high intensity war. NATO members had to change their operational plans significantly and the Czech Republic was no exception. ${ }^{17}$ The Czech Republic responded to the ongoing changes in The Long Term Perspective for Defence 2030. According to the perspective, the nature of a future security and operational environment will require:

1) rapid force projection, including strategic distances;

2) ability to conduct major military operations on corps level;

3) flexibility, enhanced force readiness and mobility;

4) international cooperation, particularly higher NATO and EU responsiveness;

5) comprehensive approach - the capability of all military branches and services to conduct joint operations, as well as combined operations with the involvement of intelligence, military and civilian elements, both in the traditional battlefield, and the cyberspace and media environment. ${ }^{18}$

\section{MODULAR STRUCTURE AND TASK FORCES}

Force modularity enables the formation of task forces ${ }^{19}$ for specific operations on the basis of original units. Nevertheless, there are two sides of the force modularity and the key question is where an effective level of modularity can be found. The creation of specific task force at a low organisational level limits the rapid force projection and ability to conduct major military operations at a corps level. The necessity to respond to a wide range of operations does not mean that all operations require forming task force at numerous organisational levels. There should always be some basic type of operation that tactical combat units can conduct without modifying their organisational structure.

16 Stuart E. Johnson, John E. Peters, Karin E. Kitchens, Aaron Martin, A Review of the Army's Modular Force Structure, RAND Corporation, 2011, p 41.

17 Pikner, Ivo, Dyčka, Lukáš, Operační koncepce a použití ozbrojených sil v budoucích operacích, Vojenské rozhledy, 2014, roč. 23 (55), no. 1, p. 87, ISSN 1210-3292

18 Ministry of Defence of the Czech Republic: The Long Term Perspective for Defence 2030, Prague 2015.

19 Task force: "temporary grouping of units, under one commander, formed for the purpose of carrying out a specific operation or mission", APP-6, Slovník NATO s termíny a definicemi, Úřad pro obrannou standardizaci, Praha 2015, p. 324. 
High intensity combat with a capable adversary should be the case as it requires swift reaction and presumes operation of a large force.

Some level of structural modularity is forced by the constantly and rapidly changing operational environment. However, the structure of task forces should be as unified as possible. Desirable state includes universal units with capabilities to execute different kinds of operations. It is clear that there will always be highly specific capabilities which have to be assigned to organic units according to the kind of operation and commander's priorities. Examples of such capabilities are air support, EOD units and ISTAR.

There are two levels of modularity: national and international. In an international environment, modularity (part of interoperability) of units is a precondition for the creation of joint military corps. States should contribute to join forces with units of reasonable size to ensure that the international task force has the highest possible combat capacity. National level of modularity depends on the size of national forces. At the European national level, the modularity is an option to create task groups for specific tasks such as out-of-territory stabilisation operations. At a lower tactical level, the term task force can be defined by its second meaning: "semi-permanent organization of units, under one commander, formed for the purpose of carrying out a continuing specific task."20 The modularity of force organisation cannot reflect all possible specific tasks and task force variants. A modular organisation is, contrary to specific tasks, a permanent and pre-planned structure. Therefore, a modular organisation cannot create particular modules and structures for each possible task. The military organisation needs a more constant basis for building its structure rather than a constantly changing list of possible future tasks. Warfighting or combat functions can provide the desired analytical basis for the planning of the unit structure.

\section{WARFIGHTING FUNCTIONS AND OPERATIONAL SCENARIOS}

Different scenarios of the use of armed forces do not necessarily require modular composed units from the lowest tactical level. There are basic functions that the combat unit must be able to perform regardless of the nature of the operation. These functions are referred to as war fighting functions or combat functions. The US Army's doctrine refers to 6 "traditional" warfighting functions:

1. mission command;

2. movement;

3. intelligence;

4. fires;

5. sustainment;

6. protection. $^{\mathbf{2 1}}$

20 Ibid. p. 324.

21 ADRP 3-0, Operations, US Department of the Army 2016, p. 2-5. 
The NATO doctrine uses similar definitions and list of combat functions. ${ }^{22}$

"The combat functions are: an analytical tool for commanders and staff that provides a complete description of all the functions that military organisations do in planning, conducting and consolidating operations. They describe the tactical responsibilities or functions that must be fulfilled so that forces on the battlefield may meet their objectives." 23

Therefore, the functions represent a basic guideline for organising units. Combat units must perform these functions regardless of the type of operation or level of organisation. Consequently, all combat units should have an organisational structure that enables them to execute the warfighting functions at some basic level. The demand for versatile forces does not affect these functions. The modular organisation enables a commander to receive extra capabilities in concordance with operational scenario to perform selected functions at a higher level.

Warfighting functions are common to all combat units at the tactical level. While the relative importance of the combat functions may vary according to the purpose of an operation, together they form a coherent whole - the basis of a balanced force's combined capabilities. ${ }^{24}$ Table 1 illustrates that these functions remain the same when engaging combat units in various types of military operations. To demonstrate the importance of combat functions, the Army of the Czech Republic was chosen as an example. Four basic scenarios for the use of the Czech armed forces were identified.

- S1: Conducting combat operations within the collective defence of the territory of NATO and the EU, including military activities on the territory of the Czech Republic.

- S2: Conducting stabilisation operations, including counterinsurgency operations outside the territory of NATO and the EU.

- S3: Conducting peacekeeping operations (peace support operations) outside the territory of NATO and the EU.

- S4: Conducting operations in support of civilian authorities (humanitarian operations) in non-military crises in homeland, allied territory or outside the territory of NATO and the EU. ${ }^{25}$

Table 1: Warfighting functions in operational scenarios

\begin{tabular}{|c|c|c|c|c|}
\hline Scenarios & \multirow{2}{*}{ S1 } & \multirow{2}{*}{ S2 } & \multirow{2}{*}{ S3 } & \multirow{2}{*}{ S4 } \\
\hline Warfighting Functions & & & & \\
\hline Mission Command & $x$ & $x$ & $x$ & $x$ \\
\hline Movement & $x$ & $\mathrm{x}$ & $\mathrm{x}$ & $\mathrm{x}$ \\
\hline Intelligence & $x$ & $\mathrm{x}$ & $\mathrm{x}$ & $\mathrm{x}$ \\
\hline Fires & $X$ & $X$ & $X$ & NO \\
\hline
\end{tabular}

22 NATO Standard, ATP 3.2. Allied Joint Doctrine for Land Operations, Edition A 2016, p. 2-15

23 Ibid. pp. 2-12.

24 NATO Standard, ATP 3.2.1. Allied Land Tactics, NATO 2009, p. 2-12.

25 Dubec R., Spišák J.: Východiska tvorby modulárních struktur, Vojenské rozhledy, 2013, vol. 22 (54), no. 3, pp. 27-40, ISSN 1210-3292 


\begin{tabular}{|l|l|l|l|l|}
\hline Sustainment & $\mathrm{X}$ & $\mathrm{X}$ & $\mathrm{X}$ & $\mathrm{X}$ \\
\hline Protection & $\mathrm{X}$ & $\mathrm{X}$ & $\mathrm{x}$ & $\mathrm{X}$ \\
\hline
\end{tabular}

Table 1 clearly shows that there is no operational need for specific modular task force for each scenario at the tactical level. The tactical level combat unit will employ basic support and service capabilities in every scenario. Geographical and operational frameworks differ from operation to operation. Therefore, they cannot provide basis for permanent organisation of the unit structure. Only the functional framework represents a stable point of view for organising the forces. The modularity is a driver for connecting permanent organisation with specific operation and geographical conditions. However, each operation is inevitably connected with time. Therefore, force effectiveness and deployability require units to be as ready as possible in their basic organisational structure. Modules should enable combat units to use higher level specific capabilities but may not be a necessary condition for the deployability of units.

\section{RECOMMENDATIONS}

As mentioned above, the reaction time has once more proven to be the key element for the success of a military campaign. The present and future operational environments require a swift reaction to an unexpected development of situation. On the other hand, the force generation process for large scale operations can become a problematic point when too fragmented units are provided. Therefore, the structure of combat forces must assure a basic level of combat readiness. The above-mentioned risk is far more eminent at the international NATO level. Besides, a fragmented international task force requires a longer training period before operational use. The principle of modularity, if applied at a low organisational level, is inconsistent with the effective use of force and rapid force projection. Therefore, each combat element should have a structure that allows it to perform basic tasks without the need to be reorganised. Creating task forces should be the commander's option, not a necessity in order to deploy the combat unit.

The principle of modularity was understood differently in various NATO member states. Medium or small size armies were not able to apply modularity in its original meaning (unified support units and more independent brigades). ${ }^{\mathbf{2 6}}$ The example of the Czech Republic shows how smaller NATO member states continue to deploy units far smaller than battalion. ${ }^{27}$ Fragmentary international forces have become a standard for stabilisation operations. However, the fragmentation of NATO forces is a significant obstacle

26 For the purpose of this text, the medium size army can be defined as one that is composed of less than one combat division in active service (minimum three combat brigades plus support units). Subsequently, the small army is defined as one that is composed of less than one brigade in active service.

27 Procházka, Josef and Dyčka, Lukáš. Czech Defence Policy - Critical Assessment and Recommendations. Vojenské rozhledy. 2017, 26 (5), 41-60. DOI: 10.3849/2336-2995.26.2017.05.041-060. ISSN 1210-3292, pp. 47-52. 
for the readiness of the common allied defence of Europe. The preparation for common defence facing a strong conventional army requires adaptation of the force structure.

European NATO members should take into account that the modular force principle was developed for a large size military. The application of modularity to smaller units has its limits. From the study of the modular structure principle, some recommendations can be drawn:

1. national forces should be unified according to NATO Capability Codes and Statements; ${ }^{28}$

2. combat units (battalions and brigades) should be able to perform basic level of the warfighting functions in their original structure;

3. at the national level, the modular organisation should be used to add extra enablers to combat units (brigade combat teams);

4. there must be limits for the minimal level of the modular task force composition for an international high readiness combat force. Modularity should be primarily used to provide CS/CSS units at the level of division or higher.

\section{CONCLUSION}

The aim of the text was to examine the potential of the modular force concept and its limits. It was shown that readiness represents limits for the modular force structure once it is applied at a lower tactical level. Modularity supports operational flexibility, which does not necessarily suppose obligatory formation of task forces for each operation. On the contrary, such fragmented modularity at a national level creates an obstacle for interoperability within a large multinational corps. ${ }^{29}$ Fragmented modularity blocks rapid projection of forces at a large scale. Compilation of task units from micro modules is possible when forces are engaged in security/stabilisation operations. Such an operational scenario provides sufficient time for the process of generating and preparing forces. In the scenario of engaging in a large-scale conventional conflict with high-intensity operational deployment, the risk of deploying fragmented task forces would be unacceptable.

The limited capability of fighting in a large-scale conventional war was identified as a risk of the modular force from the beginning of the force structure reform, but for another reasons. The formation of smaller independent units (BST) required the transfer of CS and CSS capabilities from higher echelons to lover tactical levels. Such reorganisation caused a support capabilities gap at the level of division. On the other hand, modularity was often misunderstood as a way to compensate the lack of capabilities caused by force reductions. "Sharing" of support elements has never been part of the modular force concept. In fact, creation of smaller independent combat elements multiplies the requirements for CS/CSS capabilities.

28 The NATO Capabilities Codes/Statements, Supplement 1 to regular NATO Defence Planning Survey.

29 The term fragmented modularity can be used for army structure, where each operation of the combat units requires formation of task forces at all levels at the same time. 
The actual dynamic security environment requires forces capable of a swift reaction to a wide scale of simultaneous operations. The ongoing NATO command structure adaptation has focused on the enhancement of the capability to move forces and supplies. It is the task for the member states to prepare those units and supplies to be moved. CS and CSS capabilities remain the largest gap in the structure of the NATO forces. Extra investment in formation of additional support units is the only way how to apply the concept of modularity at the international large force level.

Author: $\quad$ Major Karel Zetocha, PhD., born in 1977, graduated from the Faculty of Social Studies, Masaryk University Brno in political science, international relations and European studies. He worked as assistant professor at the Institute for Strategic Studies Defense University in Brno (2007). From 2011 was assigned to the 74th Light Motorized Battalion. Currently he works at the General Staff of the Army of the Czech Republic. He professionally focuses on the issues of functioning of security forces in democracy, defense policy and military science. He is the author of the monograph Intelligence Services in the New Democracy: the Czech Republic, editor of the Military Strategy textbook and the author of many articles.

How to cite:ZETOCHA Karel. Modular Force Structure: Risk for NATO Common Defence? Vojenské rozhledy. 2019, 28 (1), 048-058. ISSN 1210-3292 (print), 23362995 (on-line). Available at: www.vojenskerozhledy.cz 